\title{
Delivery Route and the Outcome of Newborn Hearing Screening of Full-Term Neonates Born in a Public Maternal-Infant Hospital in the South of Brazil
}

\author{
Luíza Silva Vernier $^{1 \text { (1) }}$ Karoline Lemos Schneider ${ }^{1}$ (1) \\ Daniela Centenaro Levandowski ${ }^{10}$ \\ ${ }^{1}$ Graduate Program in Health Sciences, Universidade Federal de \\ Ciências da Saúde de Porto Alegre (UFCSPA), Porto Alegre, RS, Brazil \\ 2 Hospital Materno Infantil Presidente Vargas, Porto Alegre, RS, Brazil \\ Int Arch Otorhinolaryngol 2021;25(3):e365-e373.
}

\author{
Claudia Zanini2 ${ }^{(1)}$ Tatiana Paniz ${ }^{2}$
}

\begin{abstract}
Keywords

- neonatal screening

- hearing

- maternal-child health services

- public hospital

- cesarean section
\end{abstract}

\begin{abstract}
Address for correspondence Luíza Silva Vernier, Universidade Federal de Ciências da Saúde de Porto Alegre (UFCSPA), Rua Sarmento Leite, 245, Sala 207, Centro Histórico, Porto Alegre, RS, 90050-170, Brazil (e-mail: luiza.vernier@hotmail.com).
\end{abstract}

Introduction The newborn hearing screening (NHS) is the most effective strategy for detecting newborns and infants suspected to have hearing loss.

Objective To verify possible associations between the route of delivery and the results of the NHS conducted at 3 independent times $(24,36$, and 36 hours with a facilitator auricular maneuver [FAM]) in the lives of full-term newborns.

Methods A descriptive, observational, prospective study performed with a sample of 462 newborns, with a gestational age $\geq 37$ weeks, without risk indicators of hearing loss. The NHS was conducted as a routine element of the facilities, two times: at 24 and 36 hours of life. In the presence of a "failure" in the last test, a new one was immediately performed, following the FAM. Statistic analyses were carried out on the program SPSS version 21.0 (IBM Inc., Armonk, NY, USA).

Results Of the 462 newborns assessed, 304 (65.80\%) were born by vaginal delivery. There was a statistical significance of "pass" in the NHS for the 24-hour evaluation ( $p \leq 0.001$ for a vaginal delivery and $p=0.002$ for a cesarean delivery), with the prevalence of the "pass" index being higher when the baby's lifespan was greater. A statistically significant difference was not observed when the NHS results were compared by taking into account the babies' routes of delivery and the different times of life.

Conclusion These findings show that full-term babies who were born by cesarean did not show more "failure" in the NHS results, contradicting the hypothesis of the study. Furthermore, to reduce the false-negative rates, regardless of the route of delivery, this assessment should be conducted after the first 24 hours of the newborns' life.

\section{Introduction}

Hearing is one of the most complex and sensitive systems of the human body and is a skill involved in the human's social evolution. ${ }^{1}$ Hearing disabilities may hinder or prevent the speech and language development to take place, thus impairing the overall cognitive development. ${ }^{2-4}$ For that reason, science has been, for a long time now, investing in the study received

January 16, 2020

accepted

June 2, 2020

published online

September 24, 2020
DOI https://doi.org/

10.1055/s-0040-1714146.

ISSN 1809-9777.

\footnotetext{
(c) 2020. Fundação Otorrinolaringologia. All rights reserved.

This is an open access article published by Thieme under the terms of the Creative Commons Attribution-NonDerivative-NonCommercial-License, permitting copying and reproduction so long as the original work is given appropriate credit. Contents may not be used for commercial purposes, or adapted, remixed, transformed or built upon. (https://creativecommons.org/ licenses/by-nc-nd/4.0/)

Thieme Revinter Publicações Ltda., Rua do Matoso 170, Rio de Janeiro, RJ, CEP 20270-135, Brazil
} 
of hearing to allow an early diagnosis of auditory changes and, consequently, an earlier and effective intervention. ${ }^{1}$

The earlier procedure conducted for this diagnosis is the newborn hearing screening (NHS), whose intent is to identify auditory changes in newborns and infants. ${ }^{5}$ This procedure is recommended by the Brazilian health policies as the first step of a neonatal hearing health program, which, preferably, must be performed in the first days of life (24-48 hours), still in the maternity unit and, at most, during the $1^{\text {st }}$ month of life. ${ }^{6}$ The results of the tests are presented as "failed" or "passed," defined by with and without auditory changes, respectively.

The NHS consists of a test and, if necessary, a retest, based on physiological and electrophysiological hearing measures, with the goal of referring babies who have "failed" to interventions that fit the children and their families. ${ }^{6}$ The presence or absence of risk indicators of hearing loss (RIHL) should guide the protocol to be used. The most commonly used technique for newborns and infants without RIHL is the auditory evoked otoacousticemissions (OAEs). This exam is characterized by being an instrument that is used for an objective evaluation of the peripheral auditory nervous system. It identifies the OAE, which is the release of sound energy produced by the cochlea through the external ciliated cells, in response to a sound stimulus, spreading through the middle ear until it reaches external acoustic meatus. If there is no satisfactory response ("failure"), the test should be repeated with the facilitator auricular maneuver (FAM).

According to Simonek and Azevedo, ${ }^{7}$ the performance of the FAM is a fairly common procedure. This maneuver consists of the manipulation of the external acoustic meatus (EAM), with the performance of circular movements with the forefinger on the tragus, in a counterclockwise motion, and the simultaneous displacement of the pinna, in a posteroanterior direction, aided by the thumb, aiming to move the vernix caseosa (VC), hence releasing the passage of sound and the recording of the OAE. This manipulation has the intent to decrease the number of referrals that will eventually need to be retested, in the case of false-positives.

If the "failure" is still present after this maneuver, the recommendation is to take the brainstem auditory evoked potential (BAEP- automatic or in screening mode). ${ }^{6,8}$ The BAEP is comprised of a series of waves that happen in the first $10 \mathrm{~ms}$ after the presentation of the stimulus and are captured by surface electrodes positioned on the cranial surface, which then record the neural activity generated by the cochlea and brainstem auditory nerve. ${ }^{6-9}$ If necessary, there is a preestablished follow-up, based on the multidisciplinary care, for an early diagnosis of hearing loss. It should be stressed that, for newborns and infants with RIHL, the BAEP test is directly recommended-automatic or in screening mode.

The auditory system starts its development during pregnancy and, after the $20^{\text {th }}$ gestational week, the human cochlea has already a normal adult function, allowing the fetus to react to intense sound stimuli, ${ }^{10}$ often by means of fetal movements. This is also the period when the covering of the skin with a greasy material, the VC, is started. This is something secreted by the sebaceous glands of the fetus and also formed by dead skin cells of the epidermis. This adipose tissue produces heat through the oxidation of fatty acids. ${ }^{11,12}$

During the last trimester of gestation, the production of VC is increased and is associated with the intensification of the turbidity of the amniotic liquid when the end of the gestational period is approaching. ${ }^{11,12}$ After the birth, the removal of the VC of some parts of the baby's body may happen gradually. The VC may be found more easily in the folds of the skin, and is often concentrated in the EAM, which may hamper the recording of OAE during the NHS, particularly when performed in the first hours of life. Given that the VC is a fatty substance, it does not mix with water, posing a major obstacle to the registration of these waves. ${ }^{13,14}$

Therefore, it is acknowledged that the delivery route may facilitate or not the expulsion of that substance, hence producing changes in the outcome of the NHS, since the VC also acts on the minimization of friction of the baby, due to the effect of compression in the passage through the vaginal route, in a normal delivery, and as an antimicrobial coverage for the contact with the maternal genital tract. ${ }^{15}$ In this sense, studies have reported that there is a prominence of VC in neonates born by cesarean; however, its coverage is variable. ${ }^{16,17}$ Taking into account this information, it can be assumed that babies born by vaginal route would present better conditions for the expulsion and decrease of the VC and amniotic fluid, thus resulting in a lower rate of "failure" in the NHS, when compared with babies born by cesarean section.

Under this perspective, some studies analyzed the relationship between the delivery route and the outcome of the NHS. The study by Simonek and Azevedo ${ }^{7}$ performed assessments between 6 and 48 hours of life in neonates born in private maternity hospitals of Rio de Janeiro, Brazil, and found no significant association. In agreement with this, the cross-sectional study by Michelon et $\mathrm{al}^{18}$ conducted in Rio Grande do Sul, Brazil, assessed newborns who had from 13.5 to 164 hours of life, also pointing out that the "passed/failed" index did not vary depending on the route of delivery. Both studies included the possibility of retesting after the hospital discharge, an avoidance factor of NHS, ${ }^{19}$ and a comprehensive range of time slots for the implementation of the NHS, not effective in the context of hospital admission.

Aiming to improve the processes of the NHS and the significance of conducting this screening at the earliest possible opportunity, taking into account the emotional impact that a "fail," when false-negative, can have in parents and in their return with the newborn for are test, ${ }^{20}$ as well as taking into consideration the current tendency to reduce the length of the mothers' hospital stay, it becomes relevant to ask whether the route of delivery induces some change in the outcomes of the NHS, in different moments of the newborn's life. Thus, the present study had the intent to analyze and compare the results of the NHS in newborns without RIHL, based on the type of delivery (vaginal or cesarean), at different times of life $(24,36$, or 36 hours with FAM), and to characterize the sample in relation to the sociodemographic and health indicators. Based on the literature, ${ }^{20}$ the hypothesis of the present study is that babies who are born by cesarean delivery present higher 
rates of "failure" in the NHS, related to the non-removal of the VC, which is facilitated by a vaginal delivery.

\section{Method}

This is a descriptive, quantitative, observational, and prospective study, ${ }^{21}$ which was approved by the Research Ethics Committee of the institution with the number 1.587.516. The data collection only began after the ethical approval and was conducted by three researchers: a speech-hearing therapist used to NHS-related hospital procedures, performed before data collection (based on a 3-month training), and two psychology scholars. One of the scholars was responsible for collecting the data of the mother-infant dyads in medical records, and the other was accountable for the application of a sociodemographic and healthcare data sheet for mothers at the bedside. The therapist was, thus, blinded as to the type of delivery of each newborn.

The data collection was conducted from February to October 2016 and lasted $\sim 5$ minutes with the newborns and 20 minutes with mothers. The research meets the guidelines of the resolution 466/12 of the National Health Council, which regulates research involving humans within the Brazilian country, as well as the Code of Medical Ethics of the World Medical Association (Declaration of Helsinki).

The calculation of the sample size was conducted with the Program for Epidemiologists(PEPI) version 4.0, and it was based on the study by Smolin et al, ${ }^{22}$ with a significance level of $5 \%$, a power of $90 \%$, an estimated proportion of suspected auditory change of $20.7 \%$ of the neonates born by cesarean and $7.1 \%$ of the neonates born by vaginal route, having a relative risk of 3 . Therefore, a participation of 350 newborns and their mothers was estimated, with 210 of the newborns being delivered by vaginal route and 140 by cesarean section, a ratio that fits into the reality of the hospital where the study was conducted.

The sample for this study comprised 462 mother-infant dyads, admitted in the rooming-in (RI) of a maternal-infant hospital of the public health system in the South of Brazil. Of these, $304(65.80 \%)$ newborns were delivered by vaginal route and 158 (34.20\%) by cesarean section. For the selection of the sample, the following criteria were used: infants and mothers who were being treated in the RI of the hospital as long as the mothers expressed their agreement with the participation in the study by signing the informed consent form (ICF). On the other hand, as exclusion criterion was the presence of some of the RIHL designated by the Ministry of Health (2012), ${ }^{6}$ based on the guidelines of the Joint Committee on Infant Hearing $(2007)^{5}$ : a family history of permanent hearing loss in childhood; neonatal intensive care for more than 5 days; or any of the following occurrences, regardless of the time of stay: oxygenation of the extracorporeal membrane, mechanical ventilation, exposure to ototoxic drugs or loop diuretics and exsanguinate hyperbilirubinemia, which require blood transfusion; in utero infections; craniofacial anomalies; syndromes associated with hearing loss or conductive permanent hearing loss, progressive hearing loss or late manifestation; culture-positive postnatal infections as- sociated with sensorineural hearing loss; head trauma and chemotherapy, among others. The identification of these indicators was held prior to data collection.

In addition to these, the other exclusion criteria of the study were the following: a gestational age < 37 weeks (23); newborns whose mothers gave up on participating in the study (31); mothers who had some serious mental disorder that prevented their participation (4); mothers who were inmates (8) and/or presented a social condition that would hamper the access to their information and to the information of the newborn (2), and those newborns whose birth time was not compatible with the performance of the testing by the researcher (50).

The mothers were invited to participate in the study during their stay in the RI throughout the postpartum period, after having been informed about the objectives and procedures of the research and having their doubts clarified. After the voluntary acceptance of the mothers by signing the ICF, a sociodemographic and health data sheet was orally deployed, containing information on the mother and the newborn, for characterization of the sample and to search possible interfering factors in the outcome of the NHS. At the moment of contact with the mother, the sociodemographic and health data sheet was already partially filled with the data collected on the patient's record.

After completing this step, another examiner, blind to the information collected through the aforementioned sheet, would then conduct the NHS at up to two moments: 24 and 36 hours of life. When the newborn "passed" with both ears in the first assessment, the subsequent test was automatically canceled. In the event of a second "fail" at 36 hours of life, a new immediate test was conducted, with FAM being performed prior to this new test. Those infants who failed to "pass" with one or both ears (BEs) upon completion of these steps with the OAE, later performed the BAEP test, "passing," then, with BEs, as seen in - Fig. 1. The Madsen ${ }^{\circledR}$ Accuscreen (Natus Medical Denmark ApS Hoerskaetten 9, 2630 Taastrup, Denmark) was primarily used for the implementation of the NHS.

After the collection, the data were entered into a spreadsheet of the program Statistical Package for Social Sciences (SPSS) version 21.0 (IBM Corp., Armonk, NY, USA) to conduct the analyses. For continuous variables, the mean and standard deviation were used, while the absolute frequency and percentage were used for categorical variables. The comparison between categorical variables was conducted using the Pearson chi-squared test, and, for continuous variables, the Student $t$-test was used to establish a comparison between the averages. A value of $p<0.05$ was considered for the identification of a statistically significant association between the study's variables and the outcome.

To control the confounding factors in relation to "fail" in the NHS, the Poisson-based regression analysis was applied. The measure of effect used was the prevalence ratio, along with the confidence interval of $95 \%$. The criterion for the entry of the variable in the model was the presentation of $p<0.20$ in the bivariate analysis. 

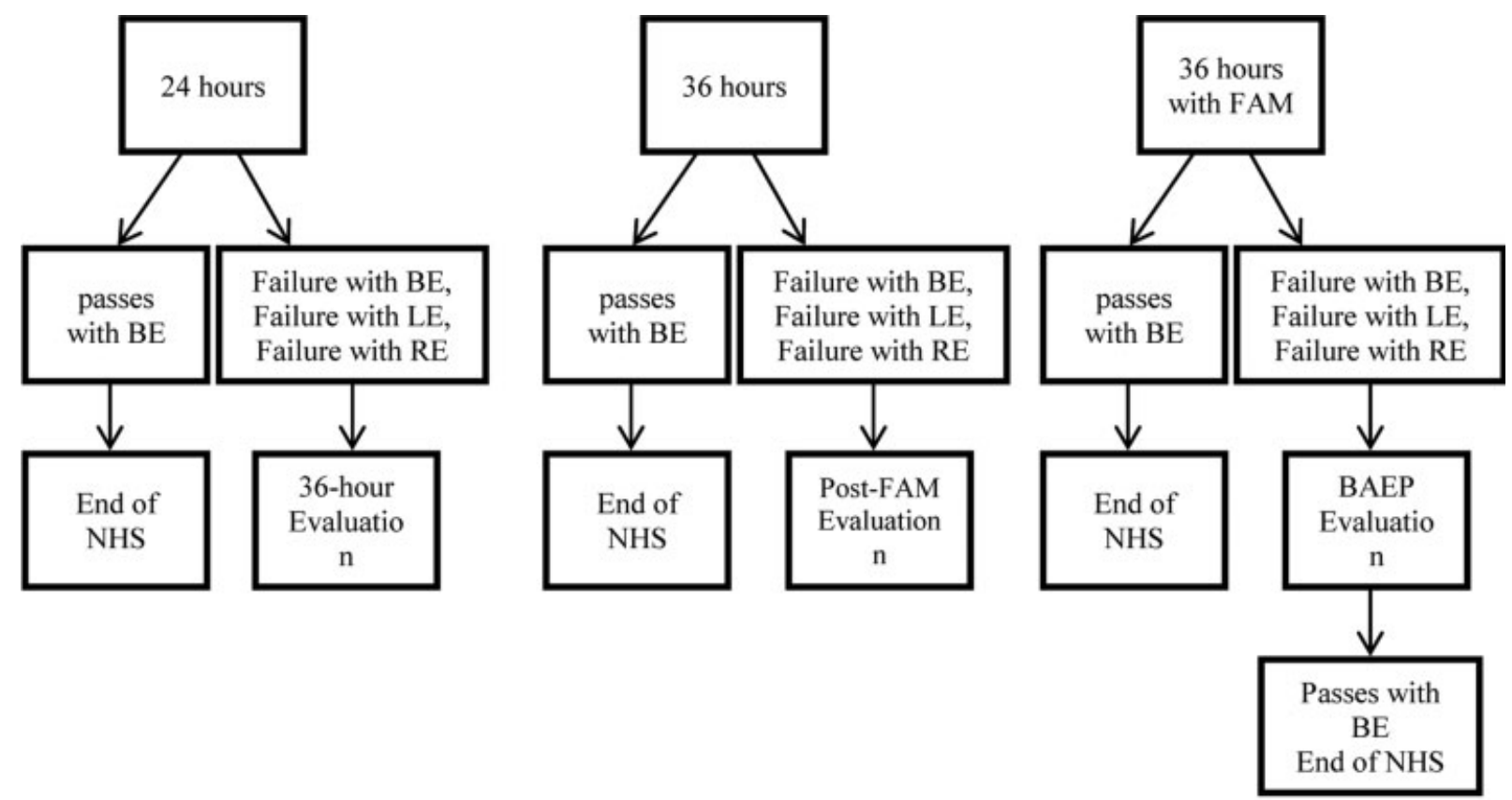

\section{LE: left ear \\ RE: right ear}

Fig. 1 Flowchart of the performance of the newborn hearing screening in this study.

Table 1 Demographic and health data of newborns, according to the route of delivery

\begin{tabular}{|c|c|c|}
\hline Variables & $\begin{array}{l}\text { Normal } \\
\text { delivery } \\
(n=304)\end{array}$ & $\begin{array}{l}\text { Cesarean } \\
\text { delivery } \\
(n=158)\end{array}$ \\
\hline \multicolumn{3}{|l|}{ Gender - n (\%) } \\
\hline Female & $166(54.6)$ & $71(44.9)$ \\
\hline Male & $138(45.4)$ & $87(55.1)$ \\
\hline Apgar $1^{\text {st }}$ minute - mean (SD) & $8.37(0.97)$ & $8.28(0.95)$ \\
\hline Apgar $5^{\text {th }}$ minute - mean (SD) & $9.40(0.60)$ & $9.28(0.61)$ \\
\hline Gestational age - mean (SD) & $\begin{array}{l}276.10 \\
(9.28)\end{array}$ & $\begin{array}{l}276.16 \\
(11.09)\end{array}$ \\
\hline Weight - mean (SD) & $\begin{array}{l}3,310.24 \\
(436.27)\end{array}$ & $\begin{array}{l}3,342.61 \\
(499.15)\end{array}$ \\
\hline Length - mean (SD) & $49.01(2.11)$ & $\begin{array}{l}48.78 \\
(2.02)\end{array}$ \\
\hline Cephalic perimeter - mean (SD) & $33.93(1.48)$ & $\begin{array}{l}34.82 \\
(1.50)\end{array}$ \\
\hline \multicolumn{3}{|l|}{ Intercurrent clinical events - n(\%) } \\
\hline Yes & $69(22.7)$ & $40(25.3)$ \\
\hline No & $235(77.3)$ & $118(74.7)$ \\
\hline
\end{tabular}

Abbreviation: SD, standard deviation.

\section{Results}

Of the 462 newborns assessed, it was attested that 166 (54.6\%) were female, and 304 (65.80\%) were born by normal delivery (vaginal). The mean gestational age was higher in the cesarean section (276.16 days) as well as the average weight of the baby $(3,342.61 \mathrm{~g})$. - Table 1 displays in detail the newborns' sociodemographic and health characteristics.

From the maternal characteristics, a prevalence of puerperal women with incomplete elementary education ( $n=228 ; 49.35 \%)$, single $(n=294 ; 63.63 \%)$, but with some romantic relationship (73.04\%), with a family income of 1 to 3 minimum wages $(n=262 ; 56.71 \%)$ and without having a pregnancy planning $(n=263 ; 56.92 \%)$ was attested. A higher mean age was found for those who underwent a cesarean delivery (27.55 years; standard deviation $[S D]=7.27$ ).

From the variables related to gestational health, a higher average number of prenatal care appointments was found for women who underwent a cesarean delivery (8.96). The largest part of the sample $(n=342 ; 74.02 \%)$ did not present complications during pregnancy or any diseases prior to pregnancy ( $n=385 ; 83.33 \%$ ), although they presented intercurrent events during the delivery ( $n=320 ; 69.29)$, such as premature contractions, changes in blood pressure and bleeding. On the other hand, 281 (60.82\%) mothers presented diseases during pregnancy, for instance gestational diabetes mellitus, urinary tract infection, and hypertension, and 174 (37.66\%) did not undergo anesthesia during the delivery. - Table 2 displays in detail the sociodemographic and health characteristics of mothers, according to the route of delivery.

As for the NHS result, based on the hours after birth of the newborns (24, 36, and 36 hours with FAM), when compared with the routes of delivery, there were no statistically significant differences in relation with "passed" or "failed" outcomes (-Table 3). Nevertheless, when the routes of delivery were separately analyzed, a significant association between the outcome "passed" in the 24-hour evaluation $(p \leq 0.001$ for 
Table 2 Demographic and health data of mothers, according to the route of delivery

\begin{tabular}{|c|c|c|}
\hline Variables & $\begin{array}{l}\text { Normal delivery } \\
(n=304)\end{array}$ & Cesarean delivery $(n=158)$ \\
\hline Maternal age (years) - mean (SD) & $24.96(6.57)$ & $27.55(7.27)$ \\
\hline \multicolumn{3}{|l|}{ Education - n (\%) } \\
\hline Incomplete basic education & $112(36.8)$ & $116(73.4)$ \\
\hline Complete basic education & $33(10.9)$ & $28(17.7)$ \\
\hline Incomplete secondary education & $67(22.0)$ & $9(5.7)$ \\
\hline Complete secondary education & $74(24.3)$ & $5(3.2)$ \\
\hline Incomplete higher education & $9(3.0)$ & $0(0.0)$ \\
\hline Complete higher education & $9(3.0)$ & $0(0.0)$ \\
\hline Illiterate & $0(0.0)$ & $0(0.0)$ \\
\hline \multicolumn{3}{|l|}{ Marital status - n (\%) } \\
\hline Single & $254(83.6)$ & $40(25.3)$ \\
\hline Married & $30(9.9)$ & $98(62.0)$ \\
\hline Stableunion & $11(3.6)$ & $20(12.7)$ \\
\hline Legally separated/divorced & $9(3.0)$ & $0(0.0)$ \\
\hline \multicolumn{3}{|l|}{ Family income- n (\%) } \\
\hline Upto 1 minimum wage & $112(36.8)$ & $39(24.7)$ \\
\hline From 1 to 3 minimum wages & $165(54.3)$ & $97(61.4)$ \\
\hline From 4 to 6 minimum wages & $23(7.6)$ & $22(13.9)$ \\
\hline Up to 7 minimum wages & $4(1.3)$ & $0(0.0)$ \\
\hline \multicolumn{3}{|l|}{ Pregnancy planning } \\
\hline Yes & $120(39.5)$ & $79(50.0)$ \\
\hline No & $184(60.5)$ & $79(50.0)$ \\
\hline \multicolumn{3}{|c|}{ Number of antenatal appointments - mean (SD) } \\
\hline & $8.24(3.43)$ & $8.96(3.46)$ \\
\hline \multicolumn{3}{|l|}{ Gestational intercurrent events - $\mathrm{n}(\%)$} \\
\hline Yes & $75(24.7)$ & $45(28.5)$ \\
\hline No & $229(75.3)$ & $113(71.5)$ \\
\hline \multicolumn{3}{|c|}{ Diseases diagnosed before pregnancy - n (\%) } \\
\hline Yes & $47(15.5)$ & $30(19.0)$ \\
\hline No & $257(84.5)$ & $128(81.0)$ \\
\hline \multicolumn{3}{|c|}{ Diseases diagnosed during pregnancy - $\mathrm{n}(\%)$} \\
\hline Yes & $179(58.9)$ & $102(64.6)$ \\
\hline No & $125(41.1)$ & $56(35.4)$ \\
\hline \multicolumn{3}{|l|}{ Type of analgesia } \\
\hline No & $174(57.2)$ & $0(0.0)$ \\
\hline Rachidian & $1(0.3)$ & $153(96.8)$ \\
\hline Epidural & $2(0.7)$ & $0(0.0)$ \\
\hline General & $0(0.0)$ & $4(2.5)$ \\
\hline Locoregional & $127(41.8)$ & $1(0.6)$ \\
\hline \multicolumn{3}{|c|}{ Delivery-associated intercurrent events } \\
\hline Yes & $262(86.2)$ & $58(36.7)$ \\
\hline No & $42(13.8)$ & $100(63.3)$ \\
\hline
\end{tabular}

Abbreviation: SD, standard deviation. 
Table 3 Time of life of the neonates when the newborn hearing screening was performed and results, according to the route of delivery

\begin{tabular}{|c|c|c|c|}
\hline Variables & $\begin{array}{l}\text { Normal delivery } \\
(n=304)\end{array}$ & $\begin{array}{l}\text { Cesarean delivery } \\
(n=158)\end{array}$ & $P$-value \\
\hline \multicolumn{4}{|c|}{24 hours - BEs } \\
\hline Passes & 217 (71.4) & $112(70.9)$ & \multirow[t]{2}{*}{0.997} \\
\hline Fails & $87(28.6)$ & $46(29.1)$ & \\
\hline \multicolumn{4}{|c|}{36 hours - BEs } \\
\hline Passes & $41(47.1)$ & $22(46.8)$ & \multirow[t]{2}{*}{1.000} \\
\hline Fails & 46 (52.9) & $25(53.2)$ & \\
\hline \multicolumn{4}{|c|}{ FAM - BEs } \\
\hline Passes & $19(41.3)$ & $11(45.8)$ & \multirow[t]{2}{*}{0.913} \\
\hline Fails & $27(58.7)$ & $13(54.2)$ & \\
\hline
\end{tabular}

Abbreviations: BEs, both ears; FAM, facilitator auricular maneuver. The maximum level of significance assumed was $5 \%(p \leq 0.05)$. The statistical analysis of these data was conducted using Pearson's chi-squared test.

vaginal delivery and $p=0.002$ for cesarean section) can be attested, with 217 (71.4\%) of the newborns having been born by vaginal and $112(70.9 \%)$ by cesarean delivery (-Chart 1), having completed the screening in a 24-hour span.

To control the possible confounding factors in relation to "failure" in the NHS, the Poisson-based regression analysis was applied. It can be attested that the evaluation at 36 hours of life was associated with the newborn's weight: for every additional kilo of the newborn, there was a reduction of $14.1 \%$ in the risk of "failure" in this assessment. The same was verified for the gestational age and the result of the NHS at 36 hours of life, because, for every additional gestational week, there was a reduction of $4 \%$ in the risk of "failure" in the NHS during that moment of the baby's life (see - Table 4 ).

\section{Discussion}

The present study had the intent to verify possible associations between the route of delivery and the results of the NHS, held at different times in the life (24, 36 and 36 hours with FAM) of full-term neonates born in a maternal-child hospital of the public health system in the South of Brazil. The NHS is the most effective means for that purpose and, therefore, the one often recommended for the diagnosis and early intervention on the hearing loss in newborns, so the complication does not have a negative impact on their development and, subsequently, on their quality of life. ${ }^{8}$ The Federal Law 12.303 , of the $2^{\text {nd }}$ of August of 2010, made the OAE examination compulsory for all children born in hospitals and maternity units in Brazil. ${ }^{23}$ Therefore, every hospital must have a speech therapist to conduct such screening.

The length of the hospital stay has been decreasing in several countries in recent decades and this trend has also been observed in Brazil, particularly after the birth itself, when the puerperal women and their newborns are healthy. Those who support an early hospital discharge affirm that it is safe and beneficial from a medical, psychosocial and economic point of view, since it narrows the number of hospital-related infections, it satisfies the patients' wish for a shorter hospital stay, and decreases hospital costs. However, an early hospital discharge is one of the aspects that may interfere with the outcome of the NHS. ${ }^{18,24}$ It is widely accepted that the

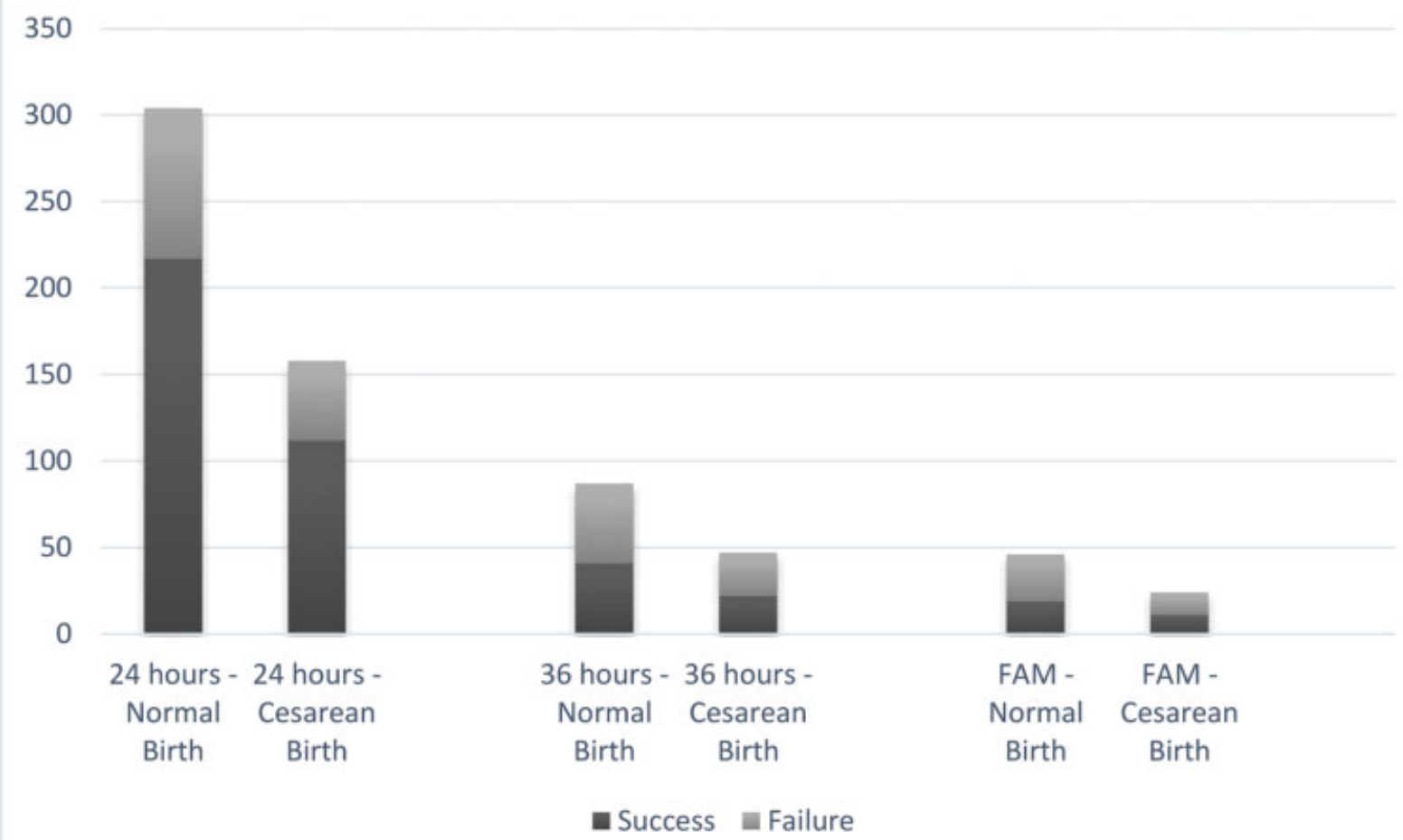

Chart 1 Index of "failure" and "passes" in the newborn hearing screening, according to the time of life of neonates and the route of delivery. The data analyzed in this chart correspond to the results obtained in both ears. 
Table 4 Maternal and baby characteristics and "failure" index in the newborn hearing screening according to the time of evaluation

\begin{tabular}{|c|c|c|c|c|c|c|c|c|c|}
\hline \multirow[t]{3}{*}{ Variables } & \multicolumn{3}{|l|}{$24 \mathrm{~h}$} & \multicolumn{3}{|l|}{$36 \mathrm{~h}$} & \multicolumn{3}{|c|}{$36 \mathrm{~h}$ with FAM } \\
\hline & \multirow[t]{2}{*}{ Failure n (\%) } & \multicolumn{2}{|l|}{ Bivariate } & \multirow[t]{2}{*}{ Failure n (\%) } & \multicolumn{2}{|l|}{ Bivariate } & \multirow[t]{2}{*}{ Failure $\mathrm{n}(\%)$} & \multicolumn{2}{|l|}{ Bivariate } \\
\hline & & $\mathrm{RP}(95 \% \mathrm{Cl})$ & $P$-value & & $\mathrm{RP}(95 \% \mathrm{Cl})$ & $P$-value & & $\begin{array}{l}\text { RP } \\
(95 \% \mathrm{Cl})\end{array}$ & $P$-value \\
\hline \multicolumn{10}{|l|}{ Gender } \\
\hline Female & $\begin{array}{l}64 \\
(27.0)\end{array}$ & & & $\begin{array}{l}35 \\
(54.7)\end{array}$ & & & $\begin{array}{l}20 \\
(57.1)\end{array}$ & & \\
\hline Male & $\begin{array}{l}69 \\
(30.7)\end{array}$ & $\begin{array}{l}1.04 \\
(0.96-1.13)\end{array}$ & 0.385 & $\begin{array}{l}36 \\
(52.2)\end{array}$ & $\begin{array}{l}0.97 \\
(0.82-1.15)\end{array}$ & 0.771 & $\begin{array}{l}20 \\
(55.6)\end{array}$ & $\begin{array}{l}0.98 \\
(0.78-1.24)\end{array}$ & 0.893 \\
\hline \multicolumn{10}{|l|}{ Type of delivery } \\
\hline Vaginal & $\begin{array}{l}87 \\
(28.6)\end{array}$ & & & $\begin{array}{l}46 \\
(52.9)\end{array}$ & & & $\begin{array}{l}27 \\
(58.7)\end{array}$ & & \\
\hline Cesarean & $\begin{array}{l}46 \\
(29.1)\end{array}$ & $\begin{array}{l}1.00 \\
(0.92-1.10)\end{array}$ & 0.911 & $\begin{array}{l}25 \\
(54.3)\end{array}$ & $\begin{array}{l}1.01 \\
(0.85-1.21)\end{array}$ & 0.871 & $\begin{array}{l}13 \\
(52)\end{array}$ & $\begin{array}{l}0.935 \\
(0.73-1.20)\end{array}$ & 0.588 \\
\hline NB weight & $\begin{array}{l}3,322.89 \pm \\
530.20\end{array}$ & $\begin{array}{l}1.00 \\
(0.91-1,11)\end{array}$ & 0.966 & $\begin{array}{l}3,243.38 \pm \\
446.63\end{array}$ & $\begin{array}{l}0.86 \\
(0.74-1.00)\end{array}$ & $0.40^{*}$ & $\begin{array}{l}3,288.63 \pm \\
409.54\end{array}$ & $\begin{array}{l}1.14 \\
(0.86-1.50)\end{array}$ & 0.356 \\
\hline $\begin{array}{l}\text { Gestational } \\
\text { age }\end{array}$ & $39.24 \pm 1.96$ & $\begin{array}{l}0.99 \\
(0.97-1,03)\end{array}$ & 0.965 & $\begin{array}{l}39.44 \pm \\
1.60\end{array}$ & $\begin{array}{l}0.96 \\
(0.93-0.99)\end{array}$ & $0.022^{*}$ & $\begin{array}{l}39.24 \pm \\
1.95\end{array}$ & $\begin{array}{l}0.98 \\
(0.94-1.02)\end{array}$ & 0.303 \\
\hline $\begin{array}{l}\text { Maternal } \\
\text { age }\end{array}$ & $25.71 \pm 7.17$ & $\begin{array}{l}0.99 \\
(0.99-1,00)\end{array}$ & 0.797 & $25.98 \pm 7.63$ & $\begin{array}{l}1.00 \\
(0.99-1.01)\end{array}$ & 0.640 & $26.07 \pm 8.18$ & $\begin{array}{l}1.00 \\
(0.98-1.01)\end{array}$ & 0.911 \\
\hline $\begin{array}{l}\text { Number of } \\
\text { prenatal } \\
\text { appointments }\end{array}$ & $8.87 \pm 3.13$ & $\begin{array}{l}1.01 \\
(0.99-1.02)\end{array}$ & 0.107 & $8.56 \pm 3.11$ & $\begin{array}{l}0.98 \\
(0.95-1.01)\end{array}$ & 0.217 & $8.35 \pm 3.22$ & $\begin{array}{l}0.98 \\
(0.95-1.02)\end{array}$ & 0.487 \\
\hline
\end{tabular}

Abbreviations: $\mathrm{Cl}$, confidence interval; FAM, facilitator auricular maneuver; NB, newborn; RP, Regression Poisson.

The statistical analysis of these data was performed using the Poisson-based regression.

performance of the NHS is indicated in the first hours of life (between 24 and 48 hours), still in the maternity ward. Nonetheless, not all admissions complete a 48 -hour period. ${ }^{6}$ Therefore, knowing the population and the process that starts during the pregnancy planning and ends with the choice of route of delivery is vital to identify aspects in which professionals can act, in accordance with the idiosyncrasies, and within the possibilities of the hospitalization span. For this reason, in the present study, it was adopted the performance of the NHS at 24, 36, and 36 hours with FAM after delivery.

Even though the literature shows that, in a vaginal delivery, the force applied by the woman at the moment of birth and the aid that the fetus adds to the whole process are elements that favor the expulsion of the amniotic fluid and, therefore, of the VC; and knowing about the prominence of the VC in cesarean delivery, ${ }^{17}$ a hypothesis was established that babies born by cesarean section would show more changes in the results of the NHS. In the meantime, in accordance with the results obtained in the present study, no statistically significant difference was observed between the time of life for the performance of the NHS $(24,36$, or 36 hours with FAM) when the route of delivery was considered. This result is in tune with the study by Michelon et al, ${ }^{18}$ which presented no differences between the results of the NHS at different times and by different routes of delivery in a sample with similar socioeconomic status and cultural context. On the other hand, the findings of the present study contradict those of the study by Farahani et al, ${ }^{20}$ which identified statistical significance in the "failure" index in accordance with the route of delivery; however, it separately considered the sample according to the type of hospital (public and private) and increased the time of retesting in up to two weeks, concluding that the performance of the NHS in cesarean-delivered newborns should be performed as close as possible to the moment of discharge, with the VC being the most important factor for that postponement. Pointing in the same direction, the findings of the present study also agree with those of Maia et al, ${ }^{25}$ who found a greater occurrence of failures in the NHS in babies born by cesarean section.

One should consider, however, that these studies have different designs and distinct populations when compared with the current study. For instance, Michelon et al ${ }^{18}$ conducted a cross-sectional study, with more restricted time intervals; however, it lacked a longitudinal assessment of those who "failed." In turn, the study of Farahani, ${ }^{20}$ despite having more restricted time intervals as well, and allocation of groups, it also divided those who were treated in a public hospital from those who were treated in a private hospital.

On the other hand, when the routes of delivery and the times of the NHS were analyzed, statistically significant associations were found between "passed" outcome in the NHS and the assessment conducted at 24 hours for babies born by vaginal and cesarean delivery. The time for the best assessment after birth has already been studied, and it is acknowledged that there is an increase in the "passed" results in the NHS when the newborn has more hours of life. ${ }^{26}$ That way, Ribas et al ${ }^{27}$ suggest that the NHS should be conducted before the hospital discharge on all newborns, but after the first 24 hours of life. 
Regarding the NHS performed at 36 hours of life, gestational age and the newborn's weight were protective factors, with every additional kilo or gestational week related to a decrease in "failure." In this sense, Onoda et $\mathrm{al}^{24}$ have also identified, in their study, a lower mean weight among children who "failed" the NHS. In a research conducted, ${ }^{28}$ in addition to the weight, the lowest gestational age was also a crucial factor for the occurrence of "failures" in the NHS. It is acknowledged that the greater the gestational age, within the standards of normality in terms of health, the more time the newborn had to develop and, consequently, more conditions for weight gain. When the opposite occurs, in other words, low birth weight and prematurity, these factors may, or are likely to, trigger pathologies, resulting in RIHL, such as a weight $<1,500 \mathrm{~g}$ at birth, a low Apgar score, mechanical ventilation, extended stay in an incubator, ototoxic medication, and hyperbilirubinemia, among others. ${ }^{28}$

Among the variables that characterized the sample, the highest maternal age at cesarean birth corroborates other national and international studies. ${ }^{29,30}$ The reasons that may explain the higher incidence of cesarean births in women of older age are several, such as the presence of diseases, fetal complications, and even obstetric indications, which include a previous cesarean birth. Regarding the education level, a prevalence of incomplete elementary education in the sample was observed. Low education can be an aggravating factor for the women's health, being considered an obstetric risk factor by the Ministry of Health, ${ }^{31}$ something that may be related to the prevalence of maternal diseases discovered in the present study during pregnancy. In the meantime, it is observed that the attendanceto a minimum of 6 prenatal appointments, previously recommended, ${ }^{31}$ was reached and even exceeded in the sample.

It was also observed the absence of a pregnancy planning among the mothers of the babies that were evaluated. An unplanned pregnancy is the one whose gestation was not planned beforehand, and it may be unwanted, when it differs from their wishes and expectations, or inappropriate, when it occurs in a period regarded as not favorable. It is, therefore, possible to establish a relationship between the pregnancy planning and the single marital status, also prevalent in the sample. It should be noted that the number of single-parent families is increasing, which have, in most cases, the mother as the responsible parent. This is happening due to the high rates of divorce and the option of many women to have a child while unmarried, in other words, due to a disengagement between parenting and conjugality. ${ }^{32}$

Finally, from the characteristics of birth of the newborns, averages within normal standards were observed, such as gestational age above 37 and below 42 weeks, which corresponds to a full-term baby ${ }^{33,34}$; the Apgar score at the $1^{\text {st }}$ and $5^{\text {th }}$ minute between 7 and 10 points; ${ }^{35}$ weight above $2,500 \mathrm{~g}$, which does not necessarily imply low weight; ${ }^{33}$ cephalic perimeter above $31.9 \mathrm{~cm}$ in boys and $31.5 \mathrm{~cm}$ in girls, thus being within the average, ${ }^{36}$ and a length between 48 and $52 \mathrm{~cm}^{37}$

\section{Conclusion}

For full-term newborns without RIHL assessed in the present study, the "pass/failure" index in the NHS, according to the time of life and the baby's routes of delivery, was not statistically significant, when a comparison was established between both. However, a higher "passed" index in the NHS in the baby's first 24 hours of life could be observed, both for those born by normal and cesarean deliveries. This way, the present study contributes with knowledge that allows the enhancement of the NHS, particularly in relation to the best time for its implementation, with the intent to decrease the indices of false-positives and the anxiety generated in parents.

For this population of the South of Brazil, belonging to a low socioeconomic stratum and having a low maternal education, the route of delivery did not interfere with the results of the NHS, hence contradicting some hypotheses found in the literature. It is thought that this constitutes a positive result, since in Brazil the indices of cesarean delivery, until recently, were above those recommended by the international health organizations.

On the other hand, the contextualization of the sociodemographic characteristics of the population, which is to be admitted, ensures the overall understanding, and also the search for qualification strategies of care, particularly in a screening service, where the NHS is a fitting piece and requires, in some situations, more than one single episode spent with the parents and the newborn, with the intent to integrate the population with the service. Speech therapists are the ones accountable for understanding the social context of the patients under the care and question the measures when it comes to improving the clinical practice.

Albeit relevant, the sample of the present study is considered to be a limitation, as it presented specific sociodemographic characteristics (predominantly of low education and low socioeconomic stratum) and was based on the same hospital, with a public profile and a high prevalence of vaginal births; another limitation was the performance of the NHS only in full-term babies, without RIHL. Therefore, further studies are needed in this field to research these aspects, considering samples with other demographic profiles (such as, for instance, different levels of education and using a private hospital as the basis) and even health conditions, including babies with low birth weight, prematurity, and other perinatal occurrences. In addition to these aspects, topics of interest for future studies would take into consideration the anxiety of parents in relation to "failure" in the NHS and the doubts and traits that hamper the pre-scheduled return for the retest.

Conflict of Interests

The authors declare that there is no conflict of interests.

\section{References}

1 Litovsky R. Development of the auditory system. Handb Clin Neurol 2015;129:55-72 
2 American Academy of Pediatrics (AAP). Erenberg A, Lemons J, Sia C, Trunkel D, Ziring P. Newborn and infant hearing loss: detection and intervention. Pediatrics 1999;103:527-530

3 American Speech-Language Hearing Association. Guidelines for audiologists providing informational and adjustment counseling to families of infants and young children with hearing loss at birth to five years of age. 2008:1-20

4 Fritzsch B, Knipper M, Friauf E. Auditory system: development, genetics, function, aging, and diseases. Cell Tissue Res 2015;361 (01):1-6

5 Joint Committee on Infant Hearing 2007 Position Statement. Principles and guidelines for early hearing detection and intervention programs. Pediatrics 2007;120:898-921

6 Brasil. Ministério da Saúde. Secretaria de Atenção à Saúde. Departamento de Ações Programáticas Estratégicas. Diretrizes de Atenção da Triagem Auditiva Neonatal. Brasília: Ministério da Saúde. 2012

7 Simonek MCS, Azevedo MF. False-positive results in newborn universal hearing screening: possible causes. Rev CEFAC 2011; 13:292-298

8 Côrtes-Andrade IF, Bento DV, Lewis DR. Emissions (TEOE): newborn hearing screening program protocols. Rev CEFAC 2013; 15:521-527

9 Romero ACL, Delecrode CR, Cardoso ACV, Frizzo ACF. Brainstem auditive evoked potential in children referred to a neonatal auditive triage program. Rev Bras Saúde Mater Infant 2012; 12:145-153

10 Russo ICP. Acústica e psicoacústica aplicadas à Fonoaudiologia, second editionSão Paulo: Lovise; 1999

11 Moraille R, Pickens WL, Visscher MO, Hoath SB. A novel role for vernix caseosa as a skin cleanser. Biol Neonate 2005;87(01):8-14

12 Sadler TW. Langman Embriologia Médica, 12 edition, Rio de Janeiro: Guanabara Koogan. 2013

13 Saffer M, Miura MS. Otite média aguda no recém-nascido e no lactente, in: Interamerican Association of Pediatric Otorhinolaryngology, V Manual de Otorrinolaringologia Pediátrica, IAPO, São Paulo. 2006

14 Marques TR, Mendes PC, Bochnia CFP, Jacob LCB, Roggia SM, Marques JM. Triagem auditiva neonatal: relação entre banho e índice de reteste. Rev Bras Otorrinolaringol 2008;74:375-381

15 Singh G, Archana G. Unraveling the mystery of vernix caseosa. Indian J Dermatol 2008;53(02):54-60

16 Visscher MO, Narendran V, Pickens WL, et al. Vernix caseosa in neonatal adaptation. J Perinatol 2005;25(07):440-446

17 Hoath SB, Pickens WL, Visscher MO. The biology of vernix caseosa. Int J Cosmet Sci 2006;28(05):319-333

18 Michelon F, Rockenbach SP, Floriano M, Delgado ED, Barba MCD. Neonatal hearing screening: index regarding the "pass"|"fail" sex, type of childbirth and the time of life. Rev CEFAC 2013; 15:1189-1195

19 Olusanya BO. Follow-up default in a hospital-based universal newborn hearing screening programme in a low-income country. Child Care Health Dev 2009;35(02):190-198
20 Farahani F, Hamidi Nahrani M, Seifrabiei MA, Emadi M. The Effect of Mode of Delivery and Hospital Type on Newborn Hearing Screening Results Using Otoacoustic Emissions: Based on Screening Age. Indian J Otolaryngol Head Neck Surg 2017;69(01):1-5

21 Köche JC. Fundamentos de Metodologia científica: teoria da ciência e iniciação à pesquisa. 28 edition, Petrópolis: Vozes.2009

22 Smolkin T, Mick O, Dabbah M, et al. Birth by cesarean delivery and failure on first otoacoustic emissions hearing test. Pediatrics 2012;130(01):e95-e100

23 Brasil. Lei $\mathrm{n}^{\circ} 12.303$, de 02 de agosto de 2010. Dispõe sobre a obrigatoriedade de realização do exame denominado Emissões Otoacústicas Evocadas. Brasília: Diário Oficial. 2010

24 Onoda RM, Azevedo MF, Santos AMN. Neonatal Hearing Screening: failures, hearing loss and risk indicators. Rev Bras Otorrinolaringol (Engl Ed) 2011;77(06):775-783

25 Maia RM, Silva MAM, Tavares PMB. Newborn hearing health: speech therapy acting on Family Health Strategy. Rev CEFAC 2011; 14:206-214

26 Lupoli LdaM, Garcia L, Anastasio ART, Fontana AC. Time after birth in relation to failure rate in newborn hearing screening. Int $\mathrm{J}$ Pediatr Otorhinolaryngol 2013;77(06):932-935

27 Ribas A, Cabral J, Gonçalves V, Gonçalves CGO, Kozlowski L. Newborn hearing screening program: the influence of the lifespan of newborn in the research of transient otoacustic emissions. Rev CEFAC 2013;15:773-777

28 Pereira PKS, Martins AS, Vieira MR, Azevedo MF. Programa de triagem auditiva neonatal: associação entre perda auditiva e fatores de risco. Pró Fono Revista Atualização Científica 2007; 19:267-278

29 Diejomaoh MFE, Al-Shamali IA, Al-Kandari F, Al-Qenae M, Mohd AT. The reproductive performance of women at 40 years and over. Eur J Obstet Gynecol Reprod Biol 2006;126(01):33-38

30 Santos GHN, Martins MdaG, Sousa MdaS, Batalha SdeJ. Impacto da idade materna sobre os resultados perinatais e via de parto. Rev Bras Ginecol Obstet 2009;31(07):326-334

31 Brasil. Ministério da Saúde. Gabinete do Ministro. Portaria GM/MS $n^{\circ} 570$, de $1^{\circ}$ de junho de 2000. Brasília, DF: Institui o Programa de Humanização do Pré-Natal e Nascimento - Incentivo à assistência Pré-natal; 2000

32 Gomes AG, Marin AH, Piccinini CA, Lopes RCS. Single mother's expectations and feelings regarding their babies. Temas Psicol 2015;23:399-411

33 World Health Organization. Comprehensive implementation plan on maternal, infant and Young child nutrition. 2012

34 Spong CY. Defining "term" pregnancy: recommendations from the Defining “Term” Pregnancy Workgroup. JAMA 2013;309(23): 2445-2446

35 American Academy of Pediatrics. American College of Obstetricians and Gynecologists. The Apgar score. Pediatrics 2006; 117:1445-1447

36 World Health Organization. Perímetro cefálico por idade. 2016

37 Kliegman R, Jenson HB, Behrman RE. Nelson - Tratado de Pediatria. 19 edition, São Paulo: Elsevier. 2013 